\title{
Ethnocentrism and Intercultural Communication Effectiveness in Multinational Companies in Indonesia: A Study in Petrochina International
}

\author{
Johannes Basuki and Anggi Marindani \\ Universitas Prof. Dr. Moestopo (Beragama) \\ Jl. Hang Lekir I No. 8, Senayan, Jakarta 10270, Indonesia \\ j_basuki07@yahoo.com
}

\begin{abstract}
This research aims at discovering and analyzing the influence of ethnocentrism to intercultural communication effectiveness in multinational companies operated in Indonesia. This research employs quantitative approach with a survey to 120 respondents as a sample of all population of active employees in the multinational company, PetroChina International Indonesia, as its' primary data source. The result of correlation analysis shows that there is a strong relation between ethnocentrism and intercultural communication effectiveness with the influence of relation tends to be negative. This gives the impression that the higher the ethnocentrism, the lower the intercultural communication effectiveness. Therefore, multinational companies must set internal policies that can keep the climate of diversity by enhancing employees' understanding of tolerance.
\end{abstract}

Keywords: Ethnocentrism; Communication; Culture; Multi-culture; Human resources

\section{Introduction}

In globalization era, the presence of multinational companies is in fact always colored by the growth of multicultural environment. This multicultural environment is a reflection of the ever changing world and market condition [1]. The condition of multicultural environment demands a more complex competence of multinational companies in successfully managing their business. Rozkwitalska in [2] perceives cultural effectiveness as the determining factor of success for companies growing in international environment. In reality, Levitt [3], Colakoglu and Caligiuri [4], Zhang and Edwards [5], and White [6] consider the factor of culture thus far hampers the success of a multicultural workenvironment and create negative dynamics such as ethnocentrism. Neuliep, et al. [7] finds that ethnocentrism tends to be the source of attraction for people to build interpersonal communication inside organization. This shows how hard it is to manage the multicultural-tended human resources. Mc Guire et al. [8] perceive the culture's characteristics as seriously determining the course of multinational companies' strategies. White [6] and Mazur [1] perceive comprehension-building as the key in managing multicultural organization. This requires the presence of a good intercultural communication.

Samovar and Richard in Liliweri [9] state that intercultural communication is a communication occurring between communicator and communicant from different cultural backgrounds. This definition means that intercultural communication requires a certain security and manner level, and a premonition of one or more of certain aspect towards the speaking partner. This theory shows that the intercultural communication effectiveness is extremely needed and plays a vital role inside a company. Intercultural communication effectiveness will provide many benefits for companies, such as fluent communication among employees as expected, a feedback or response from the 
communicator, and others. On the contrary, if the intercultural communication is lacking or even ineffective, it will indirectly give negative impact to the company, such as obstructed work process due to the difference in perception between the communicating employees, and others. This is strengthen by the theory of communication effectiveness proposed by Powers and Lowrey in Liliweri [9] namely that effective communication is the foundation of accurate communication, i.e. a communication in line with cognition (what is thought of) of two or three individuals communicating with each other. Over time, today there are more people living inside multicultural society, and more people and organization collaborates across geographical and cultural borders. This is resulted in the emergence of the need to understand cultural diversity which now becomes something that must be implanted to everyone.

From the explanations above, one of the things believed as seriously influences intercultural communication effectiveness is ethnocentrism. Ethnocentrism is essentially a view that one's culture is better than others, so this view assumes its culture as the most special. This idea is in line with theory of Ethnocentrism proposed by Nanda and Warms in Samovar, et al. [10] stating the view that one's culture is superior to other culture. It is a view that other culture can be appraised on the foundation of one's own cultural standard. Ethnocentrism is a challenge that can occur inside a community with heterogenic people. Included in it are prejudice, stereotype, discrimination, and social gap. Ethnocentrism can co-determine the effectiveness of communication. To create working harmony among employees in a company, there is a need for effective communication of every employee with distinctive cultural backgrounds. Of all arguments above, the researcher perceives that Ethnocentrism has a quite significant influence to the intercultural communication effectiveness. This is an interesting object of study in the context of Indonesia as a target for investment of multinational companies. Based on the data of Capital Investment Coordinating Board (BKPM), until 2014, there are 22,000 multinational companies registered as operating in Indonesia. On the other hand, Indonesia has 633 Large Ethnic Group (BPS-ISEAS, 2013). Cultural interaction occurring inside a multinational company in Indonesia is not just between expatriates and Indonesians, but also between people from various ethnic groups. This brings about the research question: "Is there any influence of ethnocentrism to intercultural communication effectiveness in multinational companies operating in Indonesia?"

By taking the case study in PetroChina International Company, this research aims at discovering and analyzing the influence of ethnocentrism to the intercultural communication effectiveness in multinational companies operating in Indonesia.

The rest of this paper is organized as follow. Section 2 describes multicultural dynamics inside multinational companies. Section 3 describes ethnocentrism. Section 4 presents effective intercultural communication. Section 5 present proposed method. Section 6 presents results and discussion analysis. Finally, the conclusion of this work is described in Section 7.

\section{Multicultural Dynamics Inside Multinational Companies}

The presence of multinational companies is a common thing in globalization era. Their presence becomes catalyst for global economy today. Ohmae in McGuire et al. [8] states: "towards the convergence end of the cultural spectrum, globalisation theory propounds that multinational companies are now the major vehicles for growth and that multinationals are now surpassing nation states in importance, wealth and power."

In truth, the presence of multinational companies in globalization era is always colored by the growth of multicultural environment. This, according to Mazur [1], is a reflection of conditions of the world and the market that are always in constant changes over time. This multicultural condition surely demands a more complex competence of multinational companies in managing their business successfully. Rozkwitalska in [2] explains: "the 
success that TNCs are able to achieve in an international environment is determined by many factors. The cultural effectiveness is one of them. The cultural effectiveness is an ability to reach business objectives in a culturally diversified international environment."

Culture effectiveness becomes a determining factor for the success of companies growing in international environment. In truth, culture thus far is also an inhibiting factor for the success, particularly due to cultural diversity. Colakoglu and Caligiuri [4] states that cultural distance between different national categories of employees can inhibit the knowledge transfer and integration process, as the results of this study suggest. According to Levitt [3], diversity in culture is in fact more frustrating and more of an inhibition for the creation of teamwork effectiveness than beneficial. Further, Levitt [3] sees this condition often happens in multinational work environment. He states: "despite decades of learning about and experience with cultural diversity, international work groups continue to be plagued by ethnocentrism, prejudices, and stereotypes." Similar belief is stated by White [6] who finds that in many organizations diversity creates negative dynamics such as ethnocentrism, stereotype, and conflict of cultures. He believes that this situation in time will combine and create imbalance power structure and eventually create unfavorable work environment for women and minorities. White in [6] also adds that that a conflict among groups emerges in greater size in heterogenic work organization. Ethnocentrism is indeed the main concern of many academicians. Neuliep, et al. [7] explain that ethnocentrism negatively influences international perception in organization context. In fact, McCroskey and McCain in Neuliep, et al. [7] state that further research shows that ethnocentrism tends to be the source of attraction for people in building communication in the context of cross cultural organization.

This shows how hard it is to manage human resources that tend to be multicultural. Zhang and Edwards [5] state that there are many inhibitions in creating a good standard of HR management in multinational company management. It shows that cultural approach is vital in managing multinational company. McGuire et al. [8] perceives cultural characteristics as seriously determining courses of multinational company strategy, including the culture of the company owner. McGuire et al. [8] states: "while cultural characteristics shape managerial attitudes, beliefs and values, it is the nationality of subsidiary ownership that is a strong determinant of corporate strategy." McGuire et al. [8] also divide the types of culture emerging inside multinational companies. He says:

A multinational context, they distinguish three types of culture, each exhibiting its own values and beliefs: Parent culture (Square), subsidiary culture (Triangle) and local culture (Circle). In a multinational context, embedding the subsidiary in the local culture offers the multinational corporation the opportunity to introduce sophisticated HRD practices smoothly in a non-confrontational environment.

It takes a good HR approach to unite the culture of the company owner with local culture. White [6] also perceives that a successful multicultural organization must be able to create a climate that values diversity. White [6] explains that: "a multi-culturally successful organization must value diversity. A cultural climate must allow differences to be celebrated instead of merely tolerated. All employees must understand the competitive and moral advantages of diversity. They must respect and support cultural diversity through the recognition of distinctive cultural and religious holidays, diet restrictions, and the like." Mazur [1] similarly says that: "management tools in a diverse workforce should be used to educate everyone about diversity and its issues, including laws and regulations." This gives a picture of how building understanding is the key in managing multicultural organization. 


\section{Ethnocentrism}

Nanda and Warms in Samovar, et al. [10] state that ethnocentrism is a view that one's culture is superior to other cultures. It is a view that other cultures can be appraised on the standard of one's own culture. Ethnocentrism happens when an individual perceives other cultures through the view of his own culture. Keesing in Endraswara [11] defines ethnocentrism as one's perspective of other cultures through the view of one's own culture. This view assumes that other cultures is not as good as his own or assuming his own culture as the most special.

Sumner in Endraswara [11] believes that in ethnocentrism concept, human is basically individualistic and egotistic which resulted in antagonistic (disperse) cultural phenomenon. Further Sumner gives 3 (three) aspects of ethnocentrism, namely:

a. Every community always has some social living characteristics that can be hypothesized as a syndrome,

b. Ethnocentrism syndromes are functionally related to structure and presence of groups and group competition,

c. There is a generalization that all groups show this syndrome, such as: the presence of a safe in group and underestimate of out group.

These aspects show that ethnocentrism always perceives own group norms and values as absolute to all other groups. Ethnocentrism can affect an individual or a group of individuals' life style, perception, value and prejudice towards other culture group.

Liliweri [12] suggests some types of ethnocentrism, among others:

a. Prejudice [12], that is an antipathy based on the generalization fallacy or inflexible generalization expressed as a sentiment. Prejudice can be directed towards a group as a whole or an individual as a member of the group.

b. Stereotype [12], that is assigning certain characteristics to someone based on subjective category only because that person belongs to a certain group. This characteristics assigning can either be good or bad.

c. Discrimination [12], that is a behavior produced by stereotyping or prejudice which then shown in an open action or close design to expel, shun or distance oneself, physically or socially, from a certain group.

d. Social distance Bogardus in Liliweri [12] that is a scale to measure proximity or distance felt by people from different ethnics or races.

\section{Effective Intercultural Communication}

Intercultural communication is a communication between tribes, ethnics, races and social classes. Samovar and Richards in Liliweri [12] state that intercultural communication occurs between communicator and communicant from different cultural backgrounds. In this sense, intercultural communication requires certain safety and manner level, and premonition of one or more of certain aspects to speaking partner. Followings are concepts in intercultural communication according to Liliweri [12]:

a. Ethnic is a group of people united by awareness of similarity in certain culture or subculture, or similarity in race, religion, nationality, or even certain role and function Jones in Liliweri [12].

b. Race is a group of people (sub-group human) from a community characterized by combination of physical and heredity genetic characteristics, or a combination of those factors that facilitates us to differentiate that sub-group from others Krogman in Liliweri, [12].

c. Ethnocentrism/Racism, every ethnic or race group has a spirit or ideology to declare it superior to other ethnic or race group.

d. Prejudice, is an antipathy attitude based on generalization fallacy expressed as a sentiment. Prejudice can also be directed at a group as a whole or at someone just because he is a member of the group. 
e. Multiculturalism is a concept or conditional situation of a community composed of multiple cultures. This knowledge is built by skill supporting an effective communication process, with everyone from every culture encountered, in every situation involving a group of people from different cultural backgrounds.

f. Cultural diversity, situation and condition of a community with diverse cultures emerge as a result of many cultures living in border regions between countries, nations, ethnics, races and geographies.

g. Intercultural communication is a communication between members of the same culture including all kinds of communication between members of an ethnic or a race, or communication by anyone from the same culture. This communication is considered as the weakest intercultural situation.

h. Interethnic/Interracial communication is communication between members of different ethnics or races, or communication between members of the same race who come from different culture/sub-culture backgrounds.

i. Cross cultural communication. This communication emphasizes more on comparison of interaction between people from the same cultural background or comparison of certain aspects of a culture by people from another cultural background.

j. International communication is a communication between nations and between governmental institutions from different countries. This communication occurs between two or more nations and countries with different political structure. Interaction in this scope is influenced by policies, goals, intentions, needs, and economics of a nation.

The term intercultural communication is widely used to include all kinds of communication between people from different groups or cultures. The way people communicate is influenced by culture. Those from different cultures will communicate differently. Thus, it requires an effective communication to comprehend and appreciate those diversities. The types of intercultural communication according to De Vito [13] are as follows:

a. Intercultural communication, for example between Chinese and Portuguese;

b. Interracial communication, for example between black people and white people;

c. Interethnic communication, for example between Italian descent American and Japanese descent American;

d. Inter religion communication, for example between Muslim and Jew;

e. Inter nation communication, for example between the United States and Mexico;

f. Inter sub-cultural communication, for example between a doctor and a lawyer;

g. Communication between sub-culture and dominant culture, for example between older and younger generations;

h. Communication between different sex, namely men and women.

Intercultural communication can be comprehended by analyzing the general principles.

The principles of intercultural communication according to De Vito [13] are as follows:

a. Language Relativity; Languages around the world vary in their semantic and structure characteristics. This is influenced by cognitive process, so people speaking different language will have different perspectives and thoughts. Therefore, it is vital to use effective communication techniques, such as active listening, perception checking, specific speaking, and feedback searching.

b. Language as Culture Reflection; Language reflects culture. The greater the culture diversity, the greater the communication diversity, and the harder it is to communicate. This problem can lead to miscommunication.

c. Reducing uncertainty; The greater the intercultural diversity, the greater the uncertainty and ambiguity in terms of communication [13].

d. Mindfulness and Intercultural Diversity; The greater the intercultural diversity, the greater the mindfulness of the participants during the communication activity [13]. 
e. Early Interaction and Intercultural Diversity; According to Altman and Taylor [13] intercultural diversity is particularly important in early interaction and the level of importance is gradually diminished when the relation becomes more intimate. Appraising other hastily and permanently can lead someone to misperception and misevaluation of others.

f. Maximizing result of interaction; In intercultural communication, people try to maximize the result of interaction [13]. People try to acquire maximum benefit at minimum cost.

Intercultural communication faces inhibitions and problems similar to other kinds of communication. Identifying the inhibitions in communication can help avoiding or surpassing its impact. Inhibitions in intercultural communication, according to De Vito [13], are:

a. Ignoring differences between own group and the group from different culture; The most general inhibition is considering everything as the same, there is no diversity. The opinion that people is fundamentally the same is untrue. This usually happens in value, attitude and belief.

b. Ignoring diversities between diverse cultural groups; In every cultural group, there is great and important diversities. If these diversities are ignored, it can lead to stereotype.

c. Ignoring diversities in meaning; Meaning does not lie in words used, but in the person speaking the words. In non-verbal message, the chance of diversity to happen is greater.

d. Violating Cultural Custom; Every culture has separate set of communication rules. These rules determine what is decent and indecent. For instance, in some cultures, people show respect by avoiding direct eye contact. However, in other cultures, this will be considered impolite.

e. Appraising diversity in negative way; Realizing diversities between cultures does not mean appraising them in negative way. For instance, in the United States it is considered a sign of contempt and dislike to spit in public. However, for the Masai tribe in Africa, spitting is a symbol of cordiality or goodwill.

f. Cultural Shock; Cultural shock refers to psychological reaction experienced by someone in the presence of a culture very different to his own. This is an unpleasant and frustrating situation. This cultural shock emerges because of the feeling of being isolated, conspicuous and different from others.

An effective communication can be defined as communicant's admission of the message as is delivered by communicator and then communicant confers positive response as is expected by communicator. Thus, a communication is rendered effective when there is a two way information flow between communicator and communicant and the information is equally responded as expected by the two communication actors. Liliweri [9] states that the whole process of communication in the end benefits the success of communication goal achievement level, namely how far the participants give the same meaning to the message exchanged. Powers and Lowrey in Liliweri [9] suggests that an effective communication is the foundation of accurate communication, namely a communication in line with the cognitive (what is thought) of two or three individuals in the communication.

De Vito [13] proposes several principles in creating an effective intercultural communication, namely:

a. Openness, that is an open attitude towards the present diversities, primarily concerning diversities in value, belief, and attitude, and also behavior.

b. Empathy, that is placing oneself in the position of speaking partner. Perceiving the world from different perspective will provide a new perspective in perceiving one's own culture. 
c. Supportive attitude, that is descriptive, non-evaluative, spontaneous, non-strategic, provisional, non-assuring.

d. Positive attitude, that is communicating positive attitude, particularly in intercultural situation since there are many unknown things, which prevents someone from being able to guess what is thought or felt by others.

e. Equality, that is eliminating fastidious or prejudiced attitude. Act as if we communicate with our equal.

f. Confidence, that is tolerating ambiguity, be calm in every situation and avoid being arrogant.

g. Proximity, this can unite people. The feeling of togetherness can help overcoming diversities.

h. Interaction management, that is controlling the way of speaking, both when beginning, interrupting, and ending the conversation.

i. Expression; Communicate in verbal language, but also use positive non-verbal language such as smiling, looking at the other person's eyes, and others.

j. Orienting to speaking partner; every person contributes in an interaction. Do not monopolize the conversation, moreover to speak only about ourselves. Ask question as a sign of attraction to the conversation.

Rumanti [14] finds several components in creating effective communication, namely among others: Mutual benefit between communicator and communicant; Supportive attitude by both parties; Positive attitude, meaning the thought or idea mentioned can be accepted as something benefitting both parties, Open attitude by both parties; Both parties try to adapt to speaking partner.

\section{Proposed Method}

\subsection{Framework}

Petrochina as a multinational company commits to maintain the image of being an international energy corporation with strong competitiveness and one of the main producer and distributor of petroleum and petrochemical products in the world. To materialize this, the company needs employees able to communicate widely and globally and also flexible in every condition. As a company with employees from various different cultural backgrounds, there is a high possibility of ethnocentrism occurrence which can determine the effectiveness of communication. This clarification is interpreted in a framework scheme as follows:

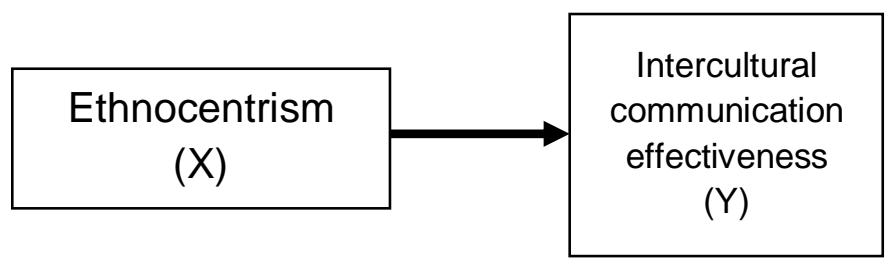

Figure 1. Proposed Research Framework

From Figure 1, Ethnocentrism variable $(\mathrm{X})$ is measured by the indicators: Prejudice; Stereotype, Discrimination, and Social Gap [12]. On the other hand, Intercultural Communication Effectiveness variable $(\mathrm{Y})$ is measured on the indicators: Mutual Interest; Supporting Each Other; Mutual Positive Attitude; Mutual Openness; and Mutual Adaptation [14]. From the framework in Figure 1 above, the following hypothesis is proposed:

Ho : Ethnocentrism has negative effect to intercultural communication effectiveness in PetroChina. 
$\mathrm{Ha}$ : Ethnocentrism has positive effect to intercultural communication effectiveness in PetroChina.

\subsection{Research Methodology}

This research employs quantitative approach [16]. The research uses primary data source collected from a survey. Primary data is collected from the questionnaire as layered scale, namely Likert, and is distributed among 120 respondents as sample. The number of samples is calculated based on sum integration using Slovin formula from the total population of 4028 of PetroChina Indonesia active employees. Sampling process is conducted by purposive sampling with a consideration to representation of ethnic/tribe inside the population. Data analysis technique employs SPSS version 21.1 by conducting validity, reliability, regression, normality, hetero-scedasticity, and autocorrelation tests. To support this research, the researcher also conducted desk study with secondary data source collected from study on literature and company documents concerning HRD.

\section{Results and Discussion Analysis}

\subsection{Company and Respondent Profile}

PetroChina International Companies in Indonesia (PetroChina) is a part of China National Petroleum Corporation (CNPC) restructuring. PetroChina is People Republic of China's corporation doing business in petroleum drilling, crude oil and natural gas refining, and crude oil and natural gas trading. At its initial foundation in 1970, PetroChina was owned by a United States company, namely Petromertrend International Limited, and then got acquired by Santa Fe Energy Resources. Then, in 2000, Santa Fe was acquired by Devon Energy, a British company. Finally, in 2002, Devon Energy was acquired by PetroChina International Companies and lasted to this day. From its history and acquisitions, it can be seen that PetroChina has gone through a lot of transitions. Those transitions, among others, are in organization's structure, culture, communication climate, and also in leadership style, and many others, recorded or not. Other most noticed transition is that the employees become very heterogenic in many aspects, such as diversity in ethnic, belief, language, custom, habit, and others. If an employee cannot adapt well into this, there will be discord and conflict that can affect the performance and productivity of the employee.

The 120 sample respondents come from multi ethnics which reflect diversities inside the company. These samples comprise of 3 from Aceh ethnic, 2 Balinese, 5 Batak ethnic, 3 Betawi ethnic, and 1 from Jambi ethnic. Then, there are 40 Javanese, 2 Kalimantan ethnic, 1 Lampung ethnic, 2 Menado ethnic, 14 Padang ethnic, 1 Palembang ethnic, 8 Papua ethnic, 8 Sumatera ethnic, 7 Sundanese, and 15 Tionghoa ethnic. It can be concluded that the majority ethnic group in PetroChina is the Javanese, amounted to 40 persons.

Table 1. Variable Description and Descriptive Statistics

\begin{tabular}{|l|r|r|r|r|r|}
\hline & $\mathrm{N}$ & Minimum & Maximum & Mean & $\begin{array}{c}\text { Std. } \\
\text { Deviation }\end{array}$ \\
\hline $\mathrm{X}$ & 120 & 21 & 99 & 55,71 & 23,136 \\
$\mathrm{Y}$ & 120 & 59 & 107 & 88,39 & 11,607 \\
Valid N & 120 & & & & \\
(listwise) & & & & & \\
\hline
\end{tabular}

Sources: SPSS Data Processing 
The result of measurement in the Table 1 above shows that $\mathrm{N}$ or total number of each variable is 120 items coming from perception of the employees in PetroChina. Ethnocentrism variable $(\mathrm{X})$ has minimum value of $21 \%$ and maximum value of $59 \%$. It can be seen in the table above that deviation standard value is less than its mean score, showing low variation between maximum and minimum value, or in other words, there is no big enough difference between lowest and highest ethnocentrism. Intercultural communication effectiveness variable (Y) has the minimum value of $99 \%$ and maximum value of $107 \%$. It can be seen in the table above that deviation standard value is smaller than its mean score, showing low variation between maximum and minimum value, or in other words, there is no big enough difference between lowest and highest intercultural communication effectiveness variable.

\subsection{Data and Assumption Quality Test}

Validity test in this research employs item validity test to measure validity level of an item to determine whether an item suitable for use or not. The method employed is Bivariate Pearson method (Product Moment Pearson). Correlation significance test is conducted by the criteria employing critical $\mathrm{r}$ with significance standard 0.05 (significance $5 \%$ or 0.05 ). There are 104 item correlated significantly with value more than 0.195 , so they can be declared valid. To measure reliability, this research employs the Cronbach's Alpha method. Reliability with Cronbach's value of 0.7 can be accepted and the value above 0.8 is good. The result of reliability test can be seen in Reliability Statistic output. The Cronbach's Alpha value of 0.849 is acquired. Since the value is above 0.8, than it is concluded that measurement tool in this research is reliable. Normality test is a test used to discover whether data population is distributed normally or not [15]. To test normality of the data, this research employs Kolmogorov-Smirnov test. Data declared normally distributed is data with significance standard of more than 0.05. From the output above, it can be seen that significance value for ethnocentrism and intercultural communication effectiveness is 0.500 (See Table 2). Since significance is more than 0.05 , it can be concluded that ethnocentrism and intercultural communication effectiveness data population is distributed normally.

Table 2. Normality Test

\begin{tabular}{|c|c|c|}
\hline \multicolumn{3}{|c|}{ One-Sample Kolmogorov-Smirnov Test } \\
\hline & & $\begin{array}{l}\text { Unstandardized } \\
\text { Residual }\end{array}$ \\
\hline \multicolumn{2}{|l|}{$\mathrm{N}$} & 120 \\
\hline \multirow{2}{*}{$\begin{array}{l}\text { Normal } \\
\text { Parameters }{ }^{\mathrm{a}, \mathrm{b}}\end{array}$} & Mean & 000 \\
\hline & Std. Deviation & 8,597 \\
\hline \multirow{3}{*}{$\begin{array}{l}\text { Most Extreme } \\
\text { Differences }\end{array}$} & Absolute &, 076 \\
\hline & Positive & ,053 \\
\hline & Negative &,- 076 \\
\hline \multicolumn{2}{|c|}{ Kolmogorov-Smirnov Z } & ,827 \\
\hline \multicolumn{2}{|c|}{ Asymp. Sig. (2-tailed) } &, 500 \\
\hline
\end{tabular}

Sources: SPSS Data Processing 

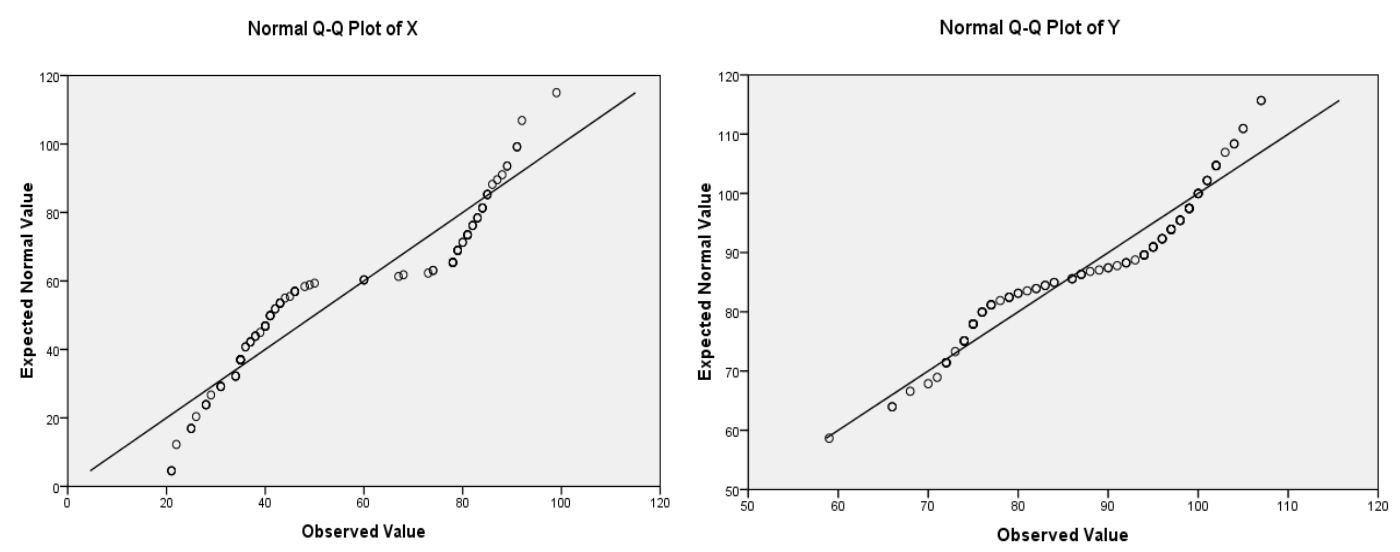

Figure 2. Q-Q Plot

From Figure 2, curve analysis of variables $X$ and $Y$ above, it can be seen that data is distributed around the diagram and follows regression model, where the dots are assembled around the test line. It can be concluded that data processed is data distributed normally so that normality test is satisfied.

Table 3. Heteroscedasticity Test

\begin{tabular}{|c|c|c|c|c|}
\hline \multicolumn{5}{|c|}{ Correlations } \\
\hline & & & $\begin{array}{l}\text { Unstandardized } \\
\text { Residual }\end{array}$ & EKAB \\
\hline \multirow{6}{*}{$\begin{array}{l}\text { Spearman's } \\
\text { rho }\end{array}$} & \multirow{3}{*}{$\begin{array}{l}\text { Unstandardiz } \\
\text { ed Residual }\end{array}$} & $\begin{array}{l}\text { Correlation } \\
\text { Coefficient }\end{array}$ & 1,000 &,- 031 \\
\hline & & Sig. (2-tailed) & . & ,738 \\
\hline & & $\mathrm{N}$ & 116 & 116 \\
\hline & \multirow{3}{*}{ EKAB } & $\begin{array}{l}\text { Correlation } \\
\text { Coefficient }\end{array}$ &,- 031 & 1,000 \\
\hline & & Sig. (2-tailed) & ,738 & . \\
\hline & & $\mathrm{N}$ & 116 & 116 \\
\hline
\end{tabular}

To test heteroscedasticity, this research employs Spearman's Rho test, namely correlating residual score (Unstandardized Residual) with each independent variable. If the result of the calculation shows correlation significance standard of more than 0.05, then there is no heteroscedasticity problem in this research. From the correlation output in Table 3, it is discovered that correlation between ethnocentrism and unstandardized residual shows significance value of 0.738 . Since significance value is more than 0.05 , it can be concluded that in regression model there is no heteroscedasticity problem.

Table 4. Autocorrelation Test

\begin{tabular}{|c|r|r|r|r|r|}
\hline \multicolumn{7}{|c|}{ Model Summary $^{\mathrm{b}}$} \\
\hline Model & \multicolumn{1}{|c|}{$\mathrm{R}$} & R Square & $\begin{array}{c}\text { Adjusted R } \\
\text { Square }\end{array}$ & $\begin{array}{c}\text { Std. Error of } \\
\text { the Estimate }\end{array}$ & $\begin{array}{c}\text { Durbin- } \\
\text { Watson }\end{array}$ \\
\hline 1 & $.672^{\mathrm{a}}$ &, 451 &, 447 & 8,633 & 1,577 \\
\hline
\end{tabular}

To test autocorrelation, this research employs Durbin-Watson (DW test) test. If $d$ is smaller from dl or bigger than (4-dl), then there is autocorrelation. From the output in 
Table 4, it can be learned that D-W value is 1.577 which mean it is before dl. So it can be concluded that in regression model there is autocorrelation.

\subsection{Results and Discussion}

The followings are the results of correlation test

Table 5. Correlation Result

\begin{tabular}{|r|l|r|r|}
\hline \multicolumn{3}{|c|}{ Correlations } \\
\hline \multirow{4}{*}{} & Pearson Correlation & \multicolumn{1}{|c|}{ X } & \multicolumn{1}{c|}{ Y } \\
\cline { 2 - 4 } & Sig. (2-tailed) & 1 & $-.672^{* *}$ \\
\cline { 2 - 4 } & N & 120 &, 000 \\
\hline \multirow{4}{*}{ Pearson Correlation } & $-.672^{* *}$ & 120 \\
\cline { 2 - 4 } & Sig. (2-tailed) &, 000 & 1 \\
\cline { 2 - 4 } & N & 120 & 120 \\
\hline
\end{tabular}

From Table 5, the result of correlation analysis $(r)$ above, it can be seen that there is correlation between ethnocentrism $(X)$ and intercultural communication effectiveness $(Y)$, with the value of 0.672 . This shows that there is a strong relation between ethnocentrism and intercultural communication effectiveness since the value is between the range $0.60-$ 0.799. Meanwhile, the direction of relation influence is negative since correlation (r) score is negative. This concludes that the higher ethnocentrism, the lower intercultural communication effectiveness. The result of the research shows that ethnocentrism through prejudice, stereotype, discrimination and social distance gives negative effect to the whole factors forming intercultural communication effectiveness in PetroChina, namely mutual interest, support each other, mutual positivity, openness, and adaptation. The quite high ethnocentrism attitude among employees has given negative effect to intercultural communication effectiveness. This is in line with ethnocentrism theory the researcher mentioned earlier from Sumner [11], namely that human is individualistic and egotistic which resulted in antagonistic (disperse) cultural phenomenon. Meanwhile, as we know, every people must cooperate well in term of communication to satisfy each other needs. This conclusion is in line with Neuliep, et al. [7] that negative ethnocentrism affects interpersonal perception in context of organization. This shows that multicultural condition present inside PetroChina Company must be noticed since it can be resulted in conflict if neglected. It is as has been said by White [6] who also added that inter group conflict emerges greater in heterogenic work organization. If this condition goes unanticipated, it will affect national interest. The opinion of Colakoglu and Caligiuri [4] is also to be noticed that cultural distance will result in inhibition of knowledge transfer. In this matter, there is a concern that knowledge transfer process from PetroChina to local HR will not happen.

\section{Conclusion}

The Correlation ( $\mathrm{r}$ ) value is negative, which shows that ethnocentrism (X) has negative effect to intercultural communication effectiveness (Y). It shows that Prejudice; Stereotype; Discrimination and Social Distance colors work environment of PetroChina Company. This should be noticed and anticipated through accurate HR policy since neglect will result in internal conflict and affect the whole company performance. A multinational company such as PetroChina must have internal policy that can guard diversity climate by enhancing employees understanding of tolerance. With the 
materialization of this policy, finally the diversity can be expected to have good effect to intercultural communication effectiveness inside the company.

\section{Acknowledgement}

This research is supported by University of Prof. Dr. Moestopo (Beragama), Jakarta, Indonesia.

\section{References}

[1] B. Mazur, "Cultural Diversity in Organisational Theory and Practice", The Journal of Intercultural Management, SWSPIZ: Poland, vol. 2, no. 2, (2010), pp. 5-15.

[2] M. Rozkwitalska, "Cultural Dilemmas of International Management", The Journal of Intercultural Management, SWSPIZ: Poland, vol. 1, no. 1, (2009), pp. 91-99.

[3] S. R. Levitt, "Cultural Factors Affecting International Teamwork Dynamics and Effectiveness", International Journal of Knowledge, Culture, and Change in Organizations: Annual Review, Common Ground Publishing, Champaign Illinois, vol. 13, (2014).

[4] S. Colakoglu and P. Caligiuri, "Cultural distance, expatriate staffing and subsidiary performance: The case of US subsidiaries of multinational corporations", The International Journal of Human Resource Management, Routledge: Taylor and Francis Group, vol. 19, no. 2, (2008), pp. 223-239.

[5] M. Zhang and C. Edwards, "HRM Practice and the Influence of "the Country of Origin" in Chinese MNC's operating in the UK", Presented in IIRA-13th World Congress, Berlin, (2003).

[6] R. D. White Jr., "Managing the Diverse Organization: The Imperative for a New Multicultural Paradigm", Public Administration \& Management: an Interactive Journal, Southern Public Administration Education Foundation, Inc. (SPAEF): Pennsylvania, vol. 4, no. 4, (1999), pp. 469-493.

[7] J. W. Neuliep, S. M. Hintz and J. C. Mcroskey, "The Influence of Ethnocentrism in Organizational Contexts: Perception of Interviewee and Managerial Attractiveness, Credibility and Effectiveness", Communication Quarterly, Routledge: Taylor and Francis Group, vol. 53, no. 1, (2015), pp. 41-56.

[8] D. McGuire, D. O'Donnell, T. N. Garavan, S. K. Saha and J. Murphy, "The Cultural Boundedness of Theory \& Practice in HRD", Presented at the Global Human Resource Management Conference, (2001); Barcelona.

[9] A. Liliweri, "Makna Budaya dalam Komunikasi AntarBudaya", Yogyakarta: LkiS, (2007).

[10] L. A. Samovar, E. P. Porter and E. R. McDaniel, "Komunikasi Lintas Budaya", (7 th $^{\text {edition}), ~ J a k a r t a: ~}$ Salemba Humanika, (2010).

[11] S. Endraswara, "Metode, Teori, Teknik Penelitian Kebudayaan: Ideologi, Epistemologi, dan Aplikasi", Yogyakarta: Pustaka Widyatama, (2006).

[12] A. Liliweri, "Prasangka dan Konflik", Yogyakarta:LkiS, (2005).

[13] J. A. DeVito, "Interpersonal Communication Book", The 13/E, New York, NY: Pearson International, (2007).

[14] M. A. Rumanti, "Dasar-Dasar Public Relations”, Jakarta: Grasindo, (2005).

[15] D. Priyatno, "Paham Analisa Statistik Data dengan SPSS", Jakarta: MediaKom, (2010).

[16] S. Arikunto, "Prosedur Penelitian: Suatu Pendekatan Praktik", Jakarta: Rineka Cipta, (2010). 


\section{Appendix}

Table: Validity Test Result

\begin{tabular}{|c|c|c|c|}
\hline Variable & $\begin{array}{c}\text { Coefficient Value } \\
\text { of Product } \\
\text { Moment } \\
\text { Correlation }\end{array}$ & $\begin{array}{c}\text { Coefficient Value of } \\
\text { Product Moment } \\
\text { Correlation }(\mathrm{N}=120, \\
\text { alfa=0.05) }\end{array}$ & Conclusion \\
\hline
\end{tabular}

Table: Reliability Test Result

\begin{tabular}{|c|c|}
\hline \multicolumn{2}{|c|}{ Reliability Statistics } \\
\hline Cronbach's Alpha & N of Items \\
\hline, 849 & 45 \\
\hline
\end{tabular}

\begin{tabular}{|c|c|c|c|c|}
\hline \multicolumn{5}{|c|}{ Item-Total Statistics } \\
\hline & $\begin{array}{c}\text { Scale Mean if } \\
\text { Item Deleted }\end{array}$ & $\begin{array}{c}\text { Scale Variance } \\
\text { if Item Deleted }\end{array}$ & $\begin{array}{c}\text { Corrected Item- } \\
\text { Total } \\
\text { Correlation }\end{array}$ & $\begin{array}{c}\text { Cronbach's } \\
\text { Alpha if Item } \\
\text { Deleted }\end{array}$ \\
\hline X1 & 141.35 & 272.801 & .787 & .832 \\
\hline X2 & 141.24 & 272.588 & .725 & .833 \\
\hline X3 & 141.45 & 270.350 & .741 & .832 \\
\hline X4 & 141.26 & 287.639 & .679 & .839 \\
\hline X5 & 141.36 & 276.820 & .716 & .835 \\
\hline X6 & 141.36 & 279.039 & .745 & .835 \\
\hline X7 & 141.25 & 278.609 & .717 & .835 \\
\hline X8 & 141.13 & 283.522 & .642 & .838 \\
\hline X9 & 141.43 & 279.188 & .758 & .835 \\
\hline X10 & 141.28 & 278.188 & .713 & .835 \\
\hline X11 & 141.37 & 270.184 & .757 & .832 \\
\hline X12 & 141.35 & 271.860 & .745 & .833 \\
\hline X13 & 141.33 & 273.650 & .750 & .833 \\
\hline X14 & 141.30 & 269.859 & .740 & .832 \\
\hline X15 & 141.33 & 273.297 & .712 & .834 \\
\hline X16 & 141.28 & 271.546 & .754 & .833 \\
\hline X17 & 141.26 & 273.319 & .737 & .833 \\
\hline X18 & 141.28 & 277.260 & .725 & .835 \\
\hline X19 & 141.35 & 274.734 & .744 & .834 \\
\hline X20 & 141.37 & 273.511 & .760 & .833 \\
\hline Y1 & 140.42 & 310.010 & -.058 & .851 \\
\hline Y2 & 140.61 & 314.963 & -.213 & .855 \\
\hline Y3 & 140.48 & 312.218 & -.137 & .853 \\
\hline & & & & \\
\hline
\end{tabular}




\begin{tabular}{|c|c|c|c|c|}
\hline Y4 & 140.43 & 312.381 & -.134 & .853 \\
\hline Y5 & 140.50 & 309.529 & -.040 & .852 \\
\hline Y6 & 140,56 & 313,543 & -.182 & .853 \\
\hline Y7 & 140.48 & 313.714 & -.177 & .854 \\
\hline Y8 & 140.43 & 315.458 & -.269 & .854 \\
\hline Y9 & 140.51 & 311.176 & -.084 & .854 \\
\hline Y10 & 141.30 & 318.817 & -.288 & .858 \\
\hline Y11 & 140.58 & 317.137 & -.273 & .856 \\
\hline Y12 & 140.47 & 314.503 & -.222 & .854 \\
\hline Y13 & 140.54 & 317.343 & -.273 & .856 \\
\hline Y14 & 140.54 & 314.049 & -.187 & .854 \\
\hline Y15 & 140.23 & 307.857 & .037 & .850 \\
\hline Y16 & 140.57 & 316.567 & -.272 & .855 \\
\hline Y17 & 140.57 & 306.886 & .046 & .850 \\
\hline Y18 & 140.54 & 314.217 & -.198 & .854 \\
\hline Y19 & 140.48 & 313.025 & -.163 & .853 \\
\hline Y20 & 140.66 & 318.899 & -.317 & .857 \\
\hline Y21 & 140.50 & 313.445 & -.178 & .853 \\
\hline Y22 & 140.96 & 317.065 & -.260 & .856 \\
\hline Y23 & 141.06 & 318.459 & -.296 & .857 \\
\hline Y24 & 140.38 & 307.146 & .078 & .849 \\
\hline Y25 & 140.33 & 308.997 & -.007 & .850 \\
\hline
\end{tabular}

